Int. J. Dev. Biol. 49: 953-960 (2005)

doi: $10.1387 / \mathrm{ijdb} .052079 \mathrm{ao}$

Original Article

\title{
Involvement of Hex in the initiation of feather morphogenesis
}

\author{
AKIKO OBINATA ${ }^{1, *}$ and YOSHIHIRO AKIMOTO² \\ ${ }^{1}$ Department of Physiological Chemistry, Faculty of Pharmaceutical Sciences, Teikyo University, Sagamiko, Kanagawa and ${ }^{2}$ Department of \\ Anatomy, Kyorin University School of Medicine, Mitaka, Tokyo, Japan
}

\begin{abstract}
In a previous study, we showed that the proline-rich divergent homeobox gene Hex/ Prh is expressed in dorsal skin of the chick embryo before and during feather bud development and that the pattern of Hex mRNA expression in the epidermis is similar to that of Wnt7a mRNA. In order to study the function of $\mathrm{Hex}$ and the relationship between $\mathrm{Hex}$ and Wnt7a in feather bud development, sense and/or antisense sequences of Hex or Wnt7a were ectopically and transiently expressed in the dorsal skin with the epidermal side toward the cathode by electroporation at the placode stage and then the skin was cultured. Increased expression of Wnt7a and $\beta$-catenin mRNA was observed in the same region where Hex-EGFP fusion protein was expressed 2 days after culture, which was followed by extra bud formation a few days later as a result of the stimulation of cell proliferation. Concomitantly, expression of Notch1 mRNA, which is expressed in normal bud development, increased in Hex-overexpressing skin. However, ectopic Wnt7a expression induced neither Hex expression nor extra bud formation in normal skin. Antisense Wnt7a specifically inhibited bud initiation in Hex-overexpressing skin but did not in normal skin. Taken together, these results suggest that $\mathrm{Hex}$ is upstream of Wnt7a and $\beta$-catenin and regulates the Wnt signaling pathway in feather bud initiation and that some other Wnt signals in addition to Wnt7a may be required for bud initiation.
\end{abstract}

KEY WORDS: homeobox gene, Hex, feather bud development, Wnt7a, $\beta$-catenin, cell proliferation

\section{Introduction}

Epithelial appendages including feathers, scales, hair, claws, teeth, etc are induced and shaped through epithelial-mesenchymal interactions (Smola etal., 1993; Chuong etal., 1996; Kishimoto et al.2000). An inductive signal from the dermis initiates formation of epidermal placodes that, in turn, induce dermal condensation in the underlying dermis(reviewed in Sengel,1976). Several molecules that mediate inductive signaling during hair and feather tract formation have been identified, including Wnts (Widelitz et al.1999; Noramly et al., 1999; Huelsken et al., 2001; Andl et al., 2002), bone morphogenetic protein (BMP) in early skin development (Scaal et al.2002), BMP inhibitor at placode stages (Patel et al., 1999), fibroblast growth factors (FGFs)(Widelitz et al., 1996; Song et al., 1996), Hedgehog (Ting-Berreth and Chuong 1996) and Notch/Delta families (Crowe et al., 1998; Viallet et al., 1998). Notch/Delta signals refine the patterning of the feather placode (Crowe et al., 1998). In situ hybridyzation studies indicated that development of dorsal feather inducing dermis is dependent on Wnt11 from the dorsomedial lip, which is induced by Wnt 1 from the dorsal neural tube (Olivera-Martinez et al., 2001 \& 2002). Afterward, $\beta$-catenin protein is found transiently and uniformly in the nuclei of the dense dermis underlying the feather tract 1 day before appearance of placode (Noramly et al., 1999). Wnt7a is first expressed as a relatively homogeneous stripe and progressively segregated into individual feather placode in the epithelium (Widelitz et al.1999). Hence, the dermal signal, which might occur uniformly within skin, triggers the activation of promoters and repressors of feather bud fate presumably under the control of Wnt7a and Notch/Delta signals from epithelium of early placode, resulting in the establishment of a regular array of buds. Homeobox genes are a large family of transcription factors that play a fundamental role in cell differentiation during development (Gehring et al., 1994). Abnormal hair follicles were observed in transgenic mice overexpressing homeobox gene Msx-2(Jiang et al., 1999). Hair defects were observed in Hoxc13 mutant mice (Godwin \&

Abbreviations used in this paper: BMP, bone morphogenetic protein; BrdU, bromodeoxyuridine; EGFP, enhanced green fluorescent protein; FGF, fibroblast growth factor.

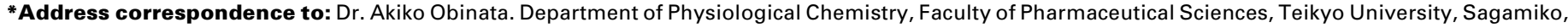
Kanagawa 199-0195, Japan. Fax: +81-426-85-3744. e-mail: akiobi@pharm.teikyo-u.ac.jp
} 

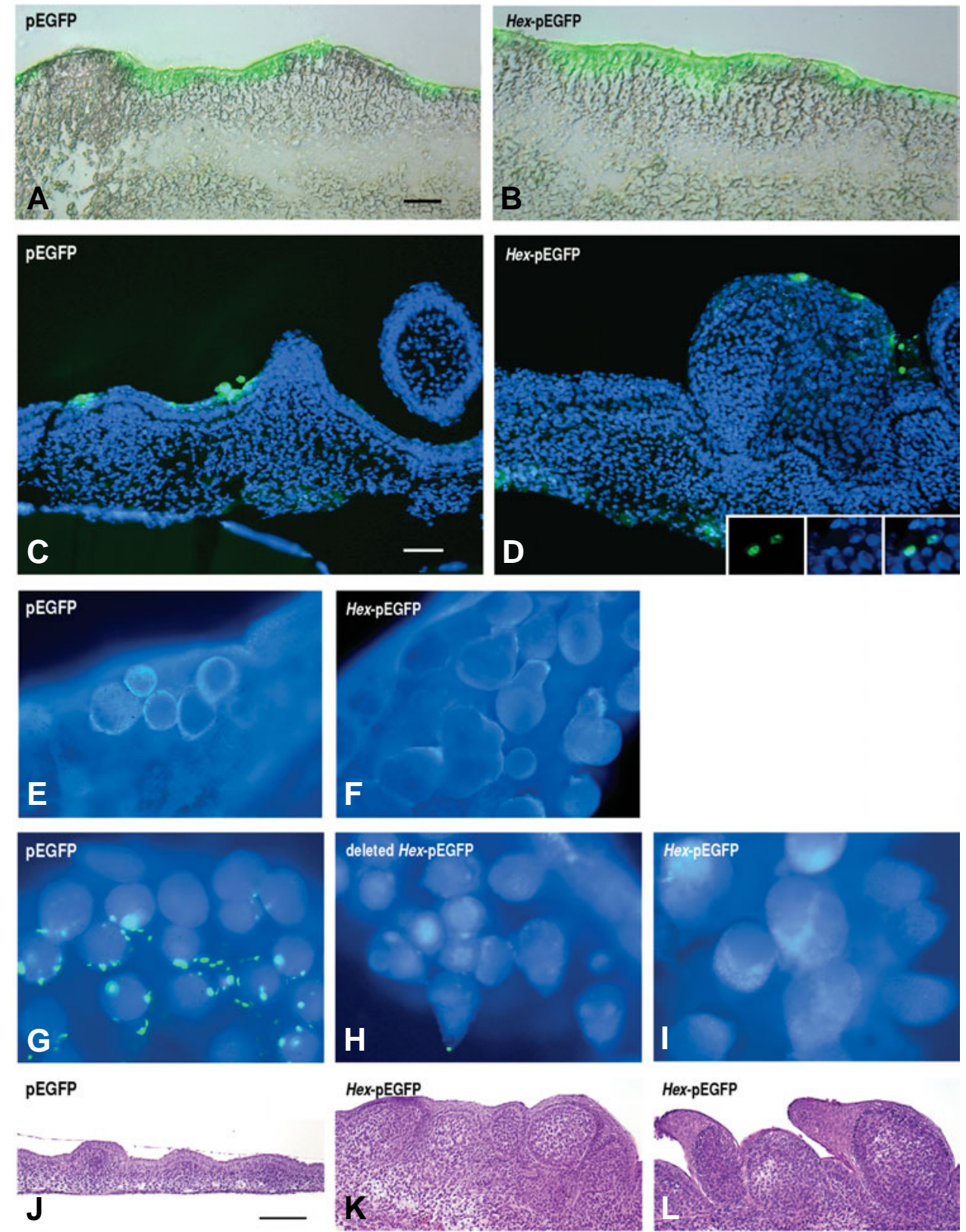

Hex-pEGFP

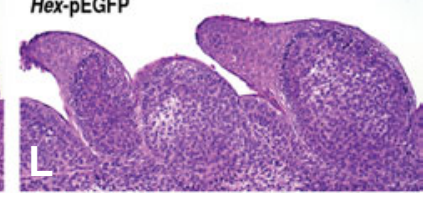

Fig. 1. Perturbation of feather bud formation by ectopic Hex expression. The epidermis of the back skin of $8(A-D, G-L)$-or $7(E, F)$-day-old-chick embryo was transfected with $p E G F P(\mathbf{A}, \mathbf{C}, \mathbf{E}, \mathbf{G}, \mathbf{J})$, Hex-pEGFP $(\mathbf{B}, \mathbf{D}, \mathbf{F}, \mathbf{I}, \mathbf{K}, \mathbf{L})$ or deleted Hex-pEGFP (deficient of N-terminal region, $\boldsymbol{H})$ by electroporation and then cultured for $1(A, B)$ or 5 days $(C-L)$. Fluorescent micrographs of skin sections of a single image of luminescence of EGFP (green, $\mathbf{A}, \mathbf{B}$ ) or double exposure images of luminescence of EGFP and DAPI (blue)-stained nuclei (C,D). Insets in (D) from left to right are luminescence of EGFP, DAPI and double exposure image. Fluorescent micrographs of intact skin of double exposure images of EGFP and DAPI (E-I). Hematoxylin and eosin-stained sections (J-L). Bar, $100 \mu \mathrm{m}$.

Capecchi 1998) and Jave-Suarez et al.(2002) showed direct involvement of $\mathrm{HOXC13}$ in the regulation of human hair keratin gene expression. The homeobox genes Msx1(Noveen etal.1995), Gbx1 (Obinata et al., 2001) and HB9 (Kosaka et al., 2000a \& 2000b) are expressed in skin and its appendages, such as hair, feather or scale and appear to be candidates for the regulation of the development of these tissues. We showed previously that divergent homeobox gene Hex/Prh is expressed in chick embryonic tarsometatarsal skin and regulates epidermal cell proliferation (Obinata et al., 2002). Hex is expressed during early stages of chick embryogenesis, including pharyngeal endoderm, endocardium, liver, thyroid gland primordia and blood islands (Yatskievych et al.1999). Hex is required for forebrain, thyroid and liver formation and blood differentiation (Keng et al.2000; MartinezBarbera et al.2000; Martinez-Barbera \& Beddington 2001). In liver morphogenesis, Hex expression in avian anterior lateral endoderm is regulated by autocrine BMP signaling (Zhang et al., 2002).

In a previous study (Obinata and Akimoto, 2005), we showed Hex expressed in dorsal skin of chick embryo before and during feather bud development and that the pattern of Hex expression in the epidermis is similar to that of Wnt7a. In order to know the relationship between Hexand Wnt7ain the feather bud morphogenesis, sense and/or antisense gene of Hexor Wnt7a were ectopically and transiently expressed in the epidermis of the dorsal skin at the placode stage by electroporation and then the skin was cultured. We indicated that Hex is upstream of Wnt7a and $\beta$-catenin and regulates $W n t$ signaling pathway in the feather bud initiation and suggested that some other Wnts in addition to Wnt7a might be involved in the bud initiation.

\section{Results}

Perturbation of feather bud formation by ectopic Hex expression

To learn the function of Hex in the skin, the back skin of a 7- or 8-day-old chick embryo that had been transfected with Hex-pEGFP or pEGFP with the epidermal side toward the cathode by electroporation was cultured for 1 - 5 days. Strong luminescence of EGFP was observed discontinuously 1 day after the culture in the epidermis and the dermis that closely contacts the epidermis (Fig. 1 A,B). Discontinuity of the luminescence was presumably caused by a different current conductivity in the skin structure. The luminescence became weak 4 days later (Fig. $1 \mathrm{C}, \mathrm{D}$ ), indicating the fusion protein and the plasmid were unstable and/or were diluted by cell proliferation during the culture. The shape of the feather bud expressing Hex-EGFP fusion 
protein was abnormal (Fig. 1D). Luminescence, which was seen exclusively in many nuclei of skin during culture for 2 days, was seldom seen in the nuclei after culture for 5 days and hence we showed the nuclei in the different region of the skin (Fig. 1D insets). Patterning of the bud after culture for 5 days was perturbed and buds were fused with each other in a snowman-like shape in the skin transfected with Hex-pEGFP (Fig. $1 \mathrm{~F}$,I) or dHexpEGFP, whose translated product is the truncated protein that contains the DNA binding domain of Hex but lacks most of the amino-terminal domain (Fig. $1 \mathrm{H}$ ), while patterning of the buds in the skin transfected with pEGFP was normal and was round in shape (Fig. 1 E,G,J). As so many buds were formed, no interbud was observed in some regions of the skin (Fig. $1 \mathrm{~K}, \mathrm{~L}$ ). Little morphological difference was observed, if any, in the skin, when we used either late 7-day-old (Fig. $1 \mathrm{E}, \mathrm{F}$ ) or early 8-day-old skin (Fig. $1 \mathrm{G}, \mathrm{I}$ ). As it is easier to manipulate, early 8-day-old skin was used in many experiments.

\section{Stimulation of epidermal cell proliferation in the interbud region of Hex-transfected skin}

To examine whether the bud formation in skin transfected with Hexwas accompanied by cell proliferation, DNA synthesis in the skin was analyzed. When ${ }^{3} \mathrm{H}$-thymidine incorporation into DNA was measured, DNA synthesis in the skin was stimulated 1.3 fold in the Hex-transfected skin $(5,816 \pm 632 \mathrm{dpm} /$ sheet) compared with control skin $(4,355 \pm 217 \mathrm{dpm} /$ sheet $)$ after 2 days of culture. While incorporation of BrdU into the nuclear DNA was seen little in the interbud than in the bud in control skin(Fig. 2 C,D), it was observed both in bud and interbud region of the skin in the Hextransfected skin (Fig. 2 A,B), indicating that the feather bud formation in the interbud epidermis was accompanied by enhanced cell proliferation induced by ectopic Hex expression.

\section{Expression of Notch1 and $\beta$-catenin in Hex- transfected skin \\ In Hex-transfected skin, $\beta$-catenin, a placode} marker (Widelitz et al., 2000), was seen throughout the epidermis with stronger expression at the lateral of the bud (Fig. 3A) and Notch-1, a posterior bud marker (Crowe et al., 1998), was seen in the epidermis of the bud region (Fig. 3C). In pEGFP-transfected skin, however, $\beta$-catenin expression was seen at the placode region (Fig. 3B), but there was little, if any, Notch-1 expression (Fig. 3D). We next examined whether expression of $\beta$-catenin will be increased in Hex-transfected skin or not in the same section. In Hex-transfected skin, $\beta$-cateninexpression was seen in the lateral of the bud in the epithelium (arrows in Fig. 4 B,D), where Hex-EGFP fusion protein was expressed (Fig. 4 A,C), while the expression (Fig. 4 $F, H$ ) was little, if any, in pEGFP-transfected skin (Fig. $4 \mathrm{E}, \mathrm{G})$. Hence, ectopic expression of Hex to the skin enhanced the property characteristics of posterior feather buds.

\section{Induction of Wnt7a in the Hex-transfected skin}

As Hex and Wnt7a are expressed in the feather primordium regions during development (Obinata and Akimoto, 2005) and expression of $\beta$-cateninincreased in the lateral of the bud in Hex-transfected skin (Figs. 3A, 4 B,D), we next examined whether Hex regulates Wnt7a expression or not. Wnt7a expression increased in the epidermis of the bud in HexpEGFP (Fig. 3 E,I) or Hex-pcDLSR $\alpha$-transfected skin (Fig. 3M) compared with that in the control skin (Fig. 3 G,J,N). Figures 3 E,F showed that, when we examined the same section, Wnt7a expression increased in the epidermal cells expressing Hex-EGFP fusion protein or in the neighborhood of the cell (arrow or arrowhead in $E$ and $F$ ) but no expression was seen in pEGFP-transfected skin (Fig. $3 \mathrm{G}, \mathrm{H}$ ). In the late 7-day-old chick embryo, there are the different phases of development resulting in the variation of bud development as was seen in Fig. 3 E,I. No increase in Hex expression was seen in Wnt7a-pcDNA-transfected skin compared with control skin (Fig. $3 \mathrm{~K}, \mathrm{~L}$ ). These results suggested that Hexis upstream gene of Wnt7aand $\beta$-catenin. In the next step, we studied whether or not Hex-induced Wnt7ais required for the bud initiation.

\section{Inhibition of Hex-induced extra bud formation by co-trans- fection of antisense Wnt7a to the skin}

Antisense Wnt7a-pcDNA was co-transfected with Hex to the dorsal skin and then the explants were cultured for 5 days. Hexinduced feather initiation (Fig. 5 A,B) was inhibited by the cotransfection of antisense Wnt7apcDNA (Fig. 5 C,D) and hence patterning seemed normal (Fig. 5C) compared with those of Hextransfected skin (Fig. 5A). However, buds with abnormal shape (arrowheads in Fig. 5D) were observed. Electron microscopic study indicated that the dermis (D) (Fig. $5 \mathrm{~N}$ ) of the abnormal bud (Fig. 5M) was separated by the epithelium (E)(Fig. $5 \mathrm{~N})$ sur-

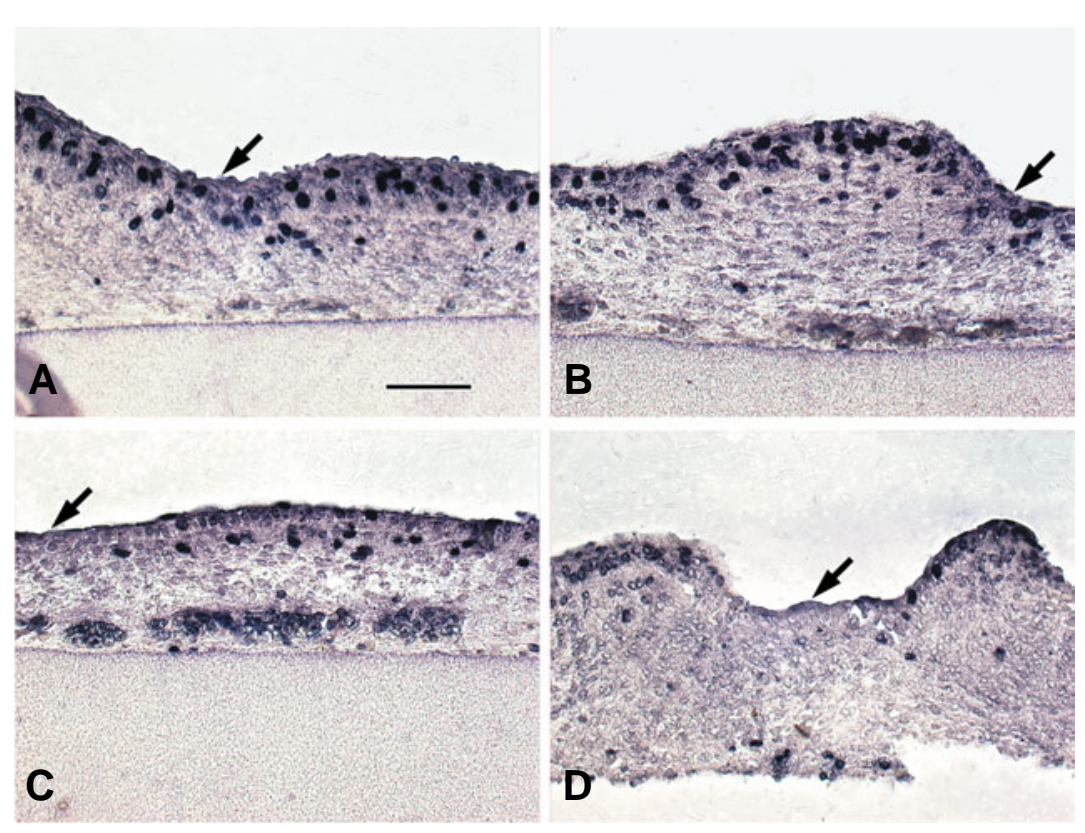

Fig. 2. Stimulation of epidermal cell proliferation in the interbud region of $\mathbf{H e x}$ transfected skin. Dorsal skin of early 8-day-old chick embryo that had been transfected with Hex-pEGFP (A,B) or pEGFP (C,D) was cultured for 2 days and was labeled with BrdU for $2 \mathrm{~h}$. Skin was analyzed immunohistochemically using anti-bromodeoxyuridine (BrdU) antibody. While incorporation of BrdU into the nuclear DNA was seen little in the interbud than in the bud in control skin $(C, D)$, it was observed both in bud and interbud region of the skin in the Hex-transfected skin (A,B). Arrows; interbud region. Bar, $100 \mu \mathrm{m}$. 

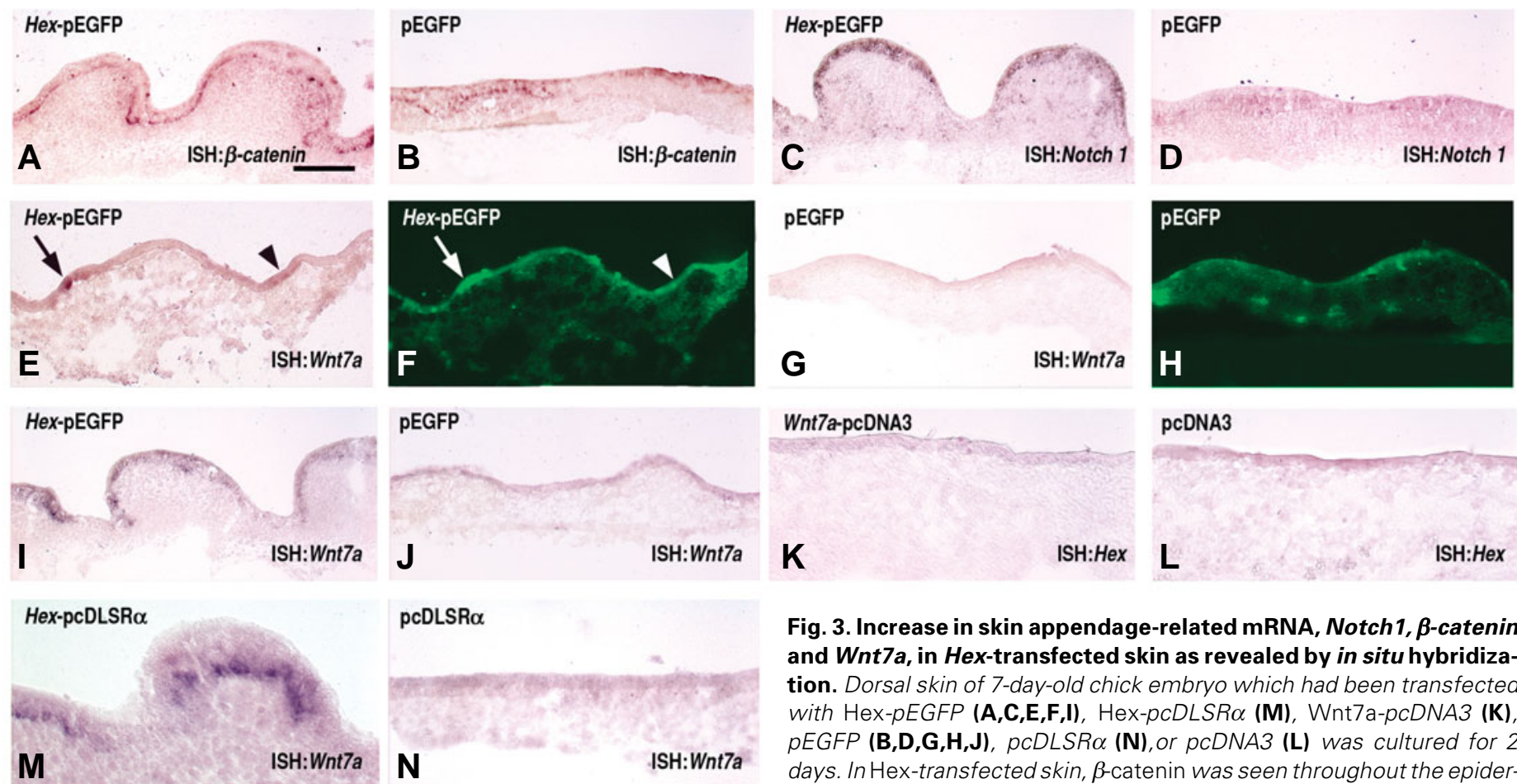

Wnt7a-pcDNA3

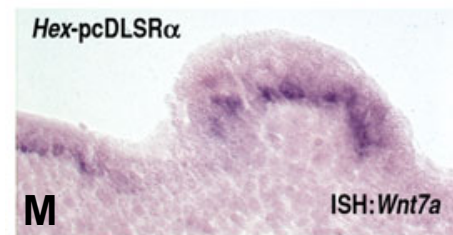

ISH:Wnt7a

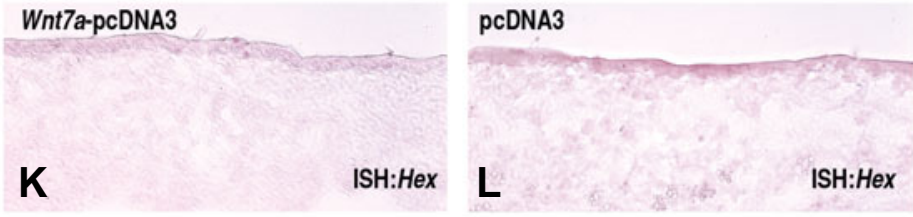

Fig. 3. Increase in skin appendage-related mRNA, Notch 1, $\beta$-catenin and $\mathbf{W n t} \mathbf{7 a}$, in Hex-transfected skin as revealed by in situ hybridization. Dorsal skin of 7-day-old chick embryo which had been transfected with Hex-pEGFP (A, C,E,F,I), Hex-pcDLSR $\alpha$ (M), Wnt7a-pcDNA3 (K), $p E G F P(\mathbf{B}, \mathbf{D}, \mathbf{G}, \mathbf{H}, \mathbf{J}), p c D L S R \alpha(\mathbf{N})$, or pcDNA3 (L) was cultured for 2 days. In Hex-transfected skin, $\beta$-catenin was seen throughout the epidermis with stronger expression at the lateral of the bud (A) and Notch-1 was seen in the epidermis of the bud region (C). In pEGFP-transfected skin, $\beta$-catenin expression was seen at the placode region (B) and there was little, if any, Notch-1 expression (D). Wnt7a expression increased in the epidermis of the bud in Hex-pEGFP (E,I) or Hex-pcDLSR $\alpha$ (M)-transfected skin compared with that in the control skin (G,J,N). Gene expression of Hex is not seen in Wnt7a-pcDNA3-transfected skin (K) or pcDNA3-transfected skin (L). While Wnt7A expression increased in the epidermal cells expressing Hex-EGFP fusion protein (arrow or arrowhead in $\mathbf{E}, \mathbf{F}$ ) in Hex-transfected epidermis, Wnt7a expression did not increase in pEGFPtransfected epidermis $\mathbf{( G , H ) . ~ B a r , ~} 100 \mu \mathrm{m}$.

rounded by basement membrane on both sides (arrowheads in insets of Fig. 5N). Next, we transfected antisense Wnt7a-pcDNA or antisense Hex to the dorsal skin and then the explants were cultured for 5 days. Neither antisense Wnt7a (Fig. 5 E,F) nor antisense Hex (Fig. $5 \mathrm{~K}, \mathrm{~L}$ ) disturbed the patterning of the feather when compared with control skin (Fig. $5 \mathrm{G}, \mathrm{H}$ ), presumably because the initiation of bud formation induced by Hex and Wnt7a in normal skin development had already completed before 8 days. Bud initiation was not seen in Wnt7a-transfected skin (Fig. $5 \mathrm{I}, \mathrm{J}$ ), suggesting that other Wnts in addition to Wnt7a might be required for the feather initiation.

\section{Discussion}

Epithelial-mesenchymal interactions are important in the morphogenesis of many organs (Sengel,1976; Smola et al., 1993; Chuong et al., 1996; Kishimoto et al.2000).

The Wnt/Wg signaling pathway plays an essential role in the early inductive events in hair and feather follicles (Widelitz et al.1999; Huelsken et al.2001; Andl et al.2002) and even in its equivalent (denticle) of fly (Dai et al.1998; Payre et al., 1999; Li et al.2002). Wnt signals (reviewed in Wodarz \& Nusse, 1998) are activated by binding to the frizzled family of transmembrane receptors and are transferred across the cell membrane. A conserved canonical Wnt signaling pathway causes stabilization of cytoplasmic $\beta$-catenin, its translocation to the nucleus and the formation of active transcription complexes between $\beta$-catenin and members of the Lef/Tcf family of DNA binding factors. Several Wnt family members (Wnt3, 3a, 4, 5a, 7a, 10a and 10b) are expressed in distinct patterns and stages in the developing skin of mammals and birds (Millar et al., 1999; Kishimoto et al., 2000; Bonifas et al., 2001; Rodriguez-Niedenfuhr et al., 2003;Reddy et al., 2001; Andl et al. 2002). It has been demonstrated that Wnt3a and $7 \mathrm{a}$ expression in epithelium, respectively, maintain anagen gene expression in vitroand their signaling to dermal papilla retain the inductive activity of hair in organ culture (Kishimoto etal.2000). The facts indicated above suggest that activation of the paracrine Wnt signaling pathway may be required for generation of chick feather buds and most pelage hair follicles.

Hex is expressed as early as at 5 days in chick embryonic dorsolateral skin and then diffusely distributed in skin before placode formation (Obinata and Akimoto, 2005). Hex expression is restricted to the placode and the dermis under the placode and later in the epidermis and the dermis of the posterior region of the short bud (Obinata and Akimoto, 2005). As the pattern of Hex expression in the epidermis is similar spatially and temporally to that of Wnt7a expression (Widelitz et al., 1999) and Hex protein exists both in cytoplasm and nucleus (Obinata and Akimoto, 2005), it was suggested that Hex is important as a transcription factor in the feather bud initiation.

We demonstrated here that ectopic expression of Hex in the skin induced expressions of Wnt7a (Fig. 3) and $\beta$-catenin(Fig. 4), 
placode markers, in the same region of Hex-expressing cell during 2 days of culture followed by extra bud formation several days later (Fig. 1). The extra bud formation was accompanied by enhanced cell proliferation in the interbud region of the dorsal skin (Fig.2) with increased expression of posterior bud marker, Notch1 (Fig. 3), suggesting an importance of cross talk between Notch1 and Wnt7a, both of which are induced by Hex, during feather bud initiation. Over expression of $W n t 7 a$ by retrovirus transfection to chick embryonic dermis and epidermis induced ectopic bud formation (Widelitz et al., 1999). As the amount of Wnt7a expression in the dermis is very small in normal bud development (Widelitz et al., 1999), we tried to express the gene mainly in the epidermis by electroporation. Ectopic Wnt7a expression in the skin induced neither extra bud formation (Fig. 5) nor Hexexpression (Fig. 3). Antisense Wnt7a specifically inhibited bud initiation in the Hex-overexpressed skin (Fig. 5). However, antisense Hexor antisense Wnt7a could not inhibit the bud formation in normal development, presumably because the bud formation induced by Hexand Wnt7a in normal skin development had already completed before 8 days and hence transfection of antisense Hex or antisense $W n t 7 a$ to the skin at early 8 days did not affect bud formation. In fact, expressions of Hex and Wnt7a in the epidermis of dorsal skin were observed as early as 6-dayold chick embryo (Obinata and Akimoto, 2005; Widelitz et al., 1999). As the dorsal skin at 6 days is so soft and small, we could not remove the skin from the embryonic body in order to study the effect of antisense Hexor antisense Wnt7aon the feather bud development. Taken together, it was suggested that Hexplays an important role in the upstream of Wnt7a signaling pathway in the feather bud initiation and some other Wnts in addition to Wnt7a, which are also induced by Hex, might be required for the bud initiation. Indeed, C-H Chang et al., (2004) showed that distinct Wnt members have positive and negative roles in forming the dermis, tracts, interbud spacing and the growth and shaping of individual buds.

Promoter sequence of human, mouse or rat Wnt7a genome has three to six Hexbinding sites (ATTAA) in $-9000 \sim-1200 \mathrm{bp}$ upstream of the gene. Hence, it is conceivable that chick wnt7a promoter is conserved between mammals and birds. Interestingly, both Hex protein and the truncated protein, which contains the DNA binding domain of Hex but lacks most of the amino-terminal domain (dHex), similarly affected the morphogenesis of skin appendages in chick embryonic dorsal (Fig. 1) and tarsometatarsal skin (Obinata et al., 2002), although the truncated protein acts as a dominant negative in
HepG2 cells (Denson et al., 2000), suggesting that the aminoterminal domain of Hex is not required for the regulation of gene expression in the case of bud formation. Further genetic studies must be done to resolve the function of the Hexin the feather (hair) follicle development.

\section{Materials and Methods}

\section{Preparation of a digoxigenin (DIG)-labeled RNA probe}

The Hex RNA probe was prepared as described previously (Obinata et al., 2002). For synthesis of a $\beta$-catenin specific probe, a DNA fragment
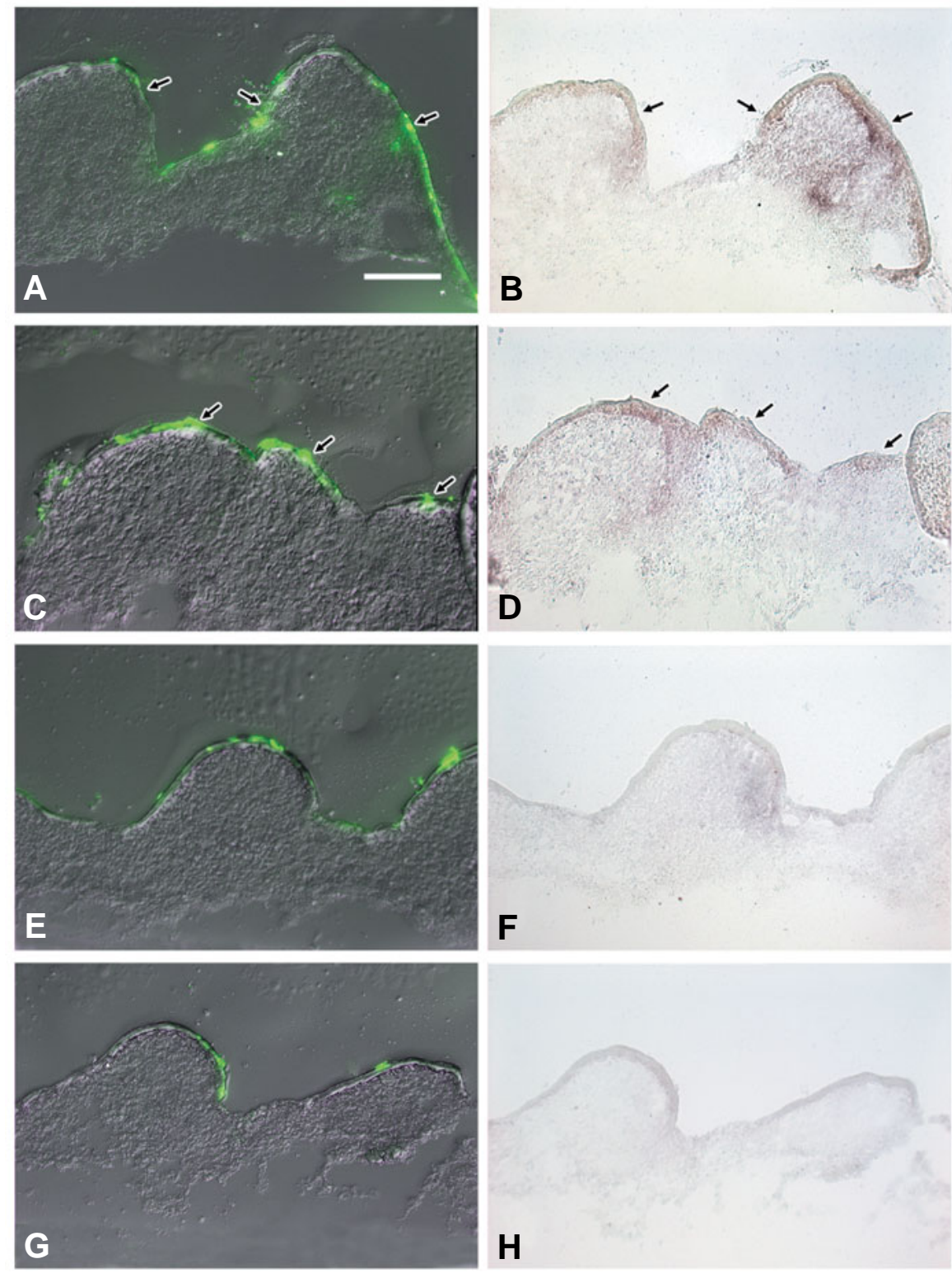

Fig. 4. Increase in $\beta$-catenin mRNA in Hex-transfected skin as revealed by in situ hybridization. Dorsal skin of early 8-day-old chick embryo, which had been transfected with Hex-pEGFP (A-D) or pEGFP (E-H), was cultured for 2 days. In Hex-transfected skin, $\beta$-catenin expression was seen at the lateral of the short bud region (arrows in $\mathrm{B}, \mathrm{D}$ ), where Hex-EGFP fusion protein was expressed (arrows in $A, C$ ), although $\beta$-catenin expression $(\mathbf{F}, \mathbf{H})$ was little, if any, in pEGFP-transfected skin (E,G). Bar, $100 \mu \mathrm{m}$. 

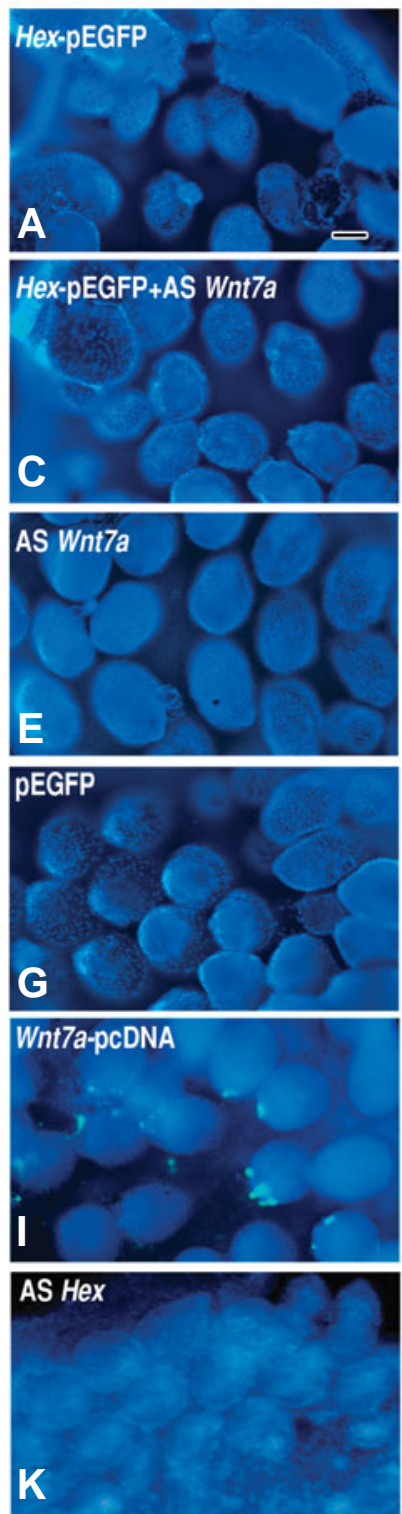

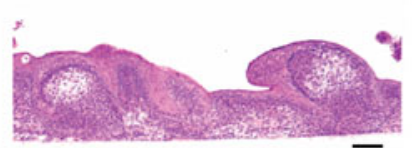

B
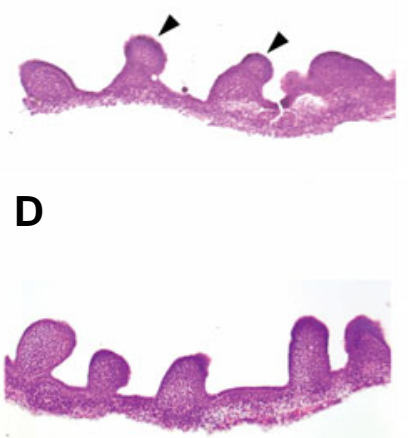

$\mathbf{F}$

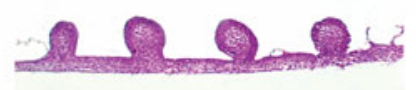

H
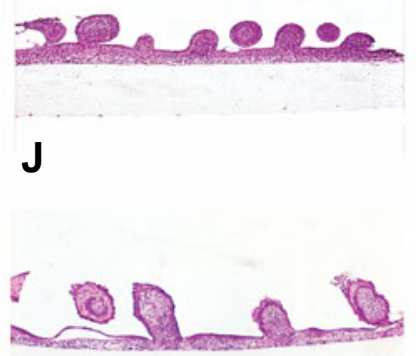

L
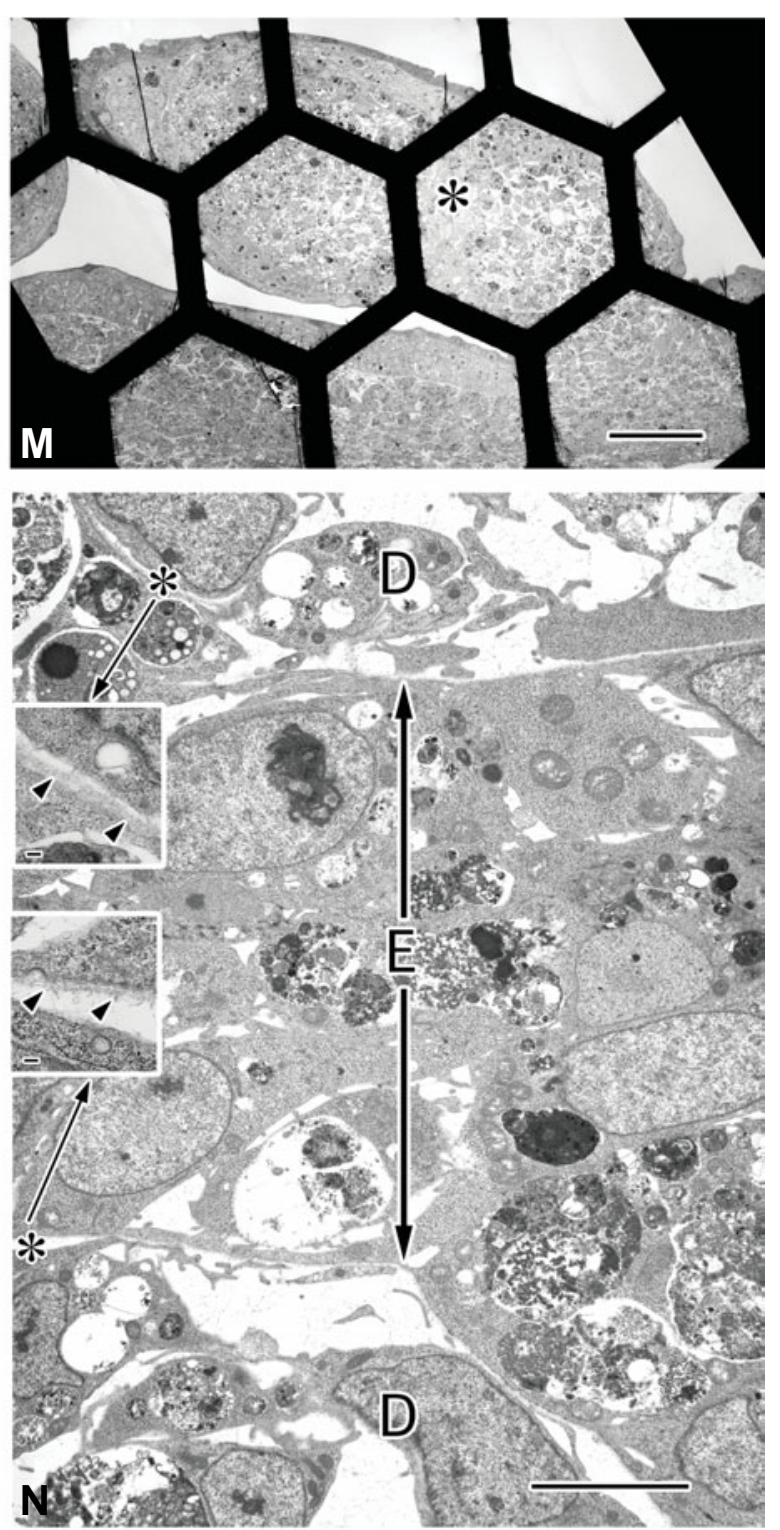

Fig. 5. Hex-induced Wnt7a is required for bud initiation. Dorsal skin of 8-day-old chick embryo, which had been transfected with plasmid, was cultured for 5 days. Feather initiation induced by Hex (A,B) was inhibited by the co-transfection of antisense Wnt7a (C,D), but abnormal buds (arrowheads in D, M), whose dermis (D) was separated by the epithelium (E) surrounded by basement membrane (arrowheads of insets of $N$ ) on both sides, were observed (M). NeitherantisenseWnt7a (E,F), Wnt7a-pcDNA3(I,J) nor antisense Hex (K-L) disturbed the patterning of the feather in normal skin. pEGFP-transfected skin $(\mathbf{G}, \mathbf{H})$. Fluorescent micrographs of intact skin of double exposure images of luminescence of EGFP (green) and DAPI (blue)-stained nuclei $(A, C, E, G, I, K)$. Hematoxylin and eosin-stained sections $(B, D, F, H, J, L)$. Electron micrographs of skin (M, N). Asterisks indicate the regions that are enlarged in the insets. Bars, $(A, B) 100 \mu \mathrm{m}$; (M) $50 \mu \mathrm{m}$; (N)10 $\mu \mathrm{m}$ and (insets) $1 \mu \mathrm{m}$.

consisting of 431 bp was amplified from skin cDNA using the following primers from 5' to 3' aagggttctctcagtcctt and gctgtttccacatcgtttg, corresponding to nucleotides $310-740$ of the published sequence. The fragment was then cloned into pT7Blue T-vector (Takara, Kusatsu, Shiga, Japan) and the resulting clone was sequenced in its entirety. For synthesis of a Wnt $7 a$ and a Notch1 specific probe, a Wnt7a cDNA fragment containing the entire coding region and a Notch $1 \mathrm{cDNA}$ fragment containing cDNA of the outside cell membrane domain, which were kindly provided by $\mathrm{Dr}$ Y.Wakamatsu (Wakamatsu et al., 2000) and Dr T.Nohno (Kawakami et al., 2000), respectively, were amplified and prepared using a standard protocol.

\section{In situ hybridization}

In situ hybridization with the DIG-labeled probe was performed as described previously (Kosaka et al., 2000a).

\section{Microscopy}

Skin explants were processed for light and electron microscopic observations as described previously (Obinata et al., 1991).

\section{Transgene construction}

A full-length Hex cDNA containing the entire Hex coding region was generously provided by Dr G.Goodwin (Haddow Labolatories, Institute of 
Cancer Research, Sutton,UK). A full length Hex and Wnt7a cDNA containing the entire Wnt7a coding region were constructed with pcDLSR $\alpha$ and pcDNA3. A full length antisense Hex and antisense Wnt7a were constructed with pcDLSR $\alpha$ and pcDNA3.1/Hygro. Hex-pEGFP and deleted Hex-pEGFP plasmids were amplified and constructed as described previously (Obinata et al. 2002).

\section{Skin culture}

Explants of 7- or early 8-day-old chick embryonic dorsal skin attached to a Millipore filter with the dermis side toward the filter were grown in DMEM. Medium was placed in the outside well and the inner chamber. A thin layer of the medium was left in the inner chamber to keep the explants moist and to provide an air-liquid interface. The explant cultures were incubated at $37^{\circ} \mathrm{C}$ in a humidified $5 \%$ carbon dioxide and $95 \%$ air incubator.

\section{Electroporation}

The back skin of 7- or 8-day-old chick embryo attached to a Millipore filter $(0.45 \mu \mathrm{m}$ pore size) was placed in a small $1 \%$ agarose chamber $(10 \mathrm{H}$

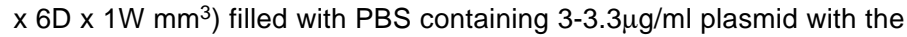
epidermal side toward the cathode by electroporation. An electro Square Portor T820 (BTX) generated square pulses (30V, pulse length $100 \mathrm{ms,}$ 7 times).

\section{Immunocytochemical assay for the detection of bromodeoxyuridine incorporation into cellular DNA}

Skin that had been transfected with Hex-pEGFP or pEGFP by electroporation was cultured for 2 days in DMEM. The cultured skin from which fluorescence had been eliminated was cut into a $2 \mathrm{~mm}^{2}$ area and incubated in the medium containing $10 \mu \mathrm{M}$ bromodeoxyuridine (BrdU) for $2 \mathrm{~h}$, fixed with Bouin solution, embedded in paraffin and cut into $5 \mu \mathrm{m}$ sections. After being dewaxed and rehydrated, the sections were incubated with anti-BrdU mouse monoclonal antibody (Boeringer Mannheim) and then with anti mouse-lg alkaline phosphatase followed (according to the manufacturer's instructions) by the substrate reaction

\section{Measurement of DNA synthesis}

Nine explants of skin were elecroporated with Hex-pEGFP or pEGFP followed by culture for 2 days. The area of explant with strong luminescence of EGFP was cut and was pulse-labeled by immersion in $2 \mu \mathrm{Ci} / \mathrm{ml}$ of [methyl-1',2'-3H] thymidine ( $86 \mathrm{Ci} / \mathrm{mmol} ;$ Amersham) for $2 \mathrm{hr}$ at $37^{\circ} \mathrm{C}$. After the skin was washed with phosphate-buffered saline, macromolecules in the epidermal homogenate were precipitated with 5\% TCA;the precipitate was collected on a Whatman GF/filter and its radioactivity was measured as dpm/sheet. As only very small amount of skin was obtained, we could not determine DNA.

\section{Acknowledgments}

We thank Dr G.Goodwin (Haddow Laboratories, Institute of Cancer Research, Sutton, UK), for providing a chick Hex cDNA; Dr Y. Wakamatsu (Division of Developmental Neuroscience, Graduate School of Medicine, Tohoku University, Sendai, Japan) for providing a quail Notch1 cDNA, and Dr T.Nohno (Departmennt of Molecular Biology, Kawasaki Medical School, Kurashiki, Japan) for providing chick Wnt7a cDNA. We are grateful to Ms. S.Matsubara andMs. T.Shibata for their technical support. This work was supported, in part, by Grants-in-Aid from the Ministry of Education, Science, Sports, Culture and Technology, Japan.

\section{References}

ANDL, T., REDDY, S. T., GADDAPARA, T. and MILLAR, S. E. (2002). Wnt signals are required for the initiation of hair follicle development. Dev. Cel/2: 643-653.

BONIFAS, J. M., PENNYPACKER, S., CHUANG, P. T., MCMAHON, A. P., WILLIAMS, M., ROSENTHAL, A., DE SAUVAGE, F. J. and EPSTEIN, E. H. JR.
(2001). Activation of expression of hedgehog target genes in basal cell carcinomas. J. Invest. Dermatol. 116: 739-742.

CHUONG, C. -M., WIDELITZ, R. B., TING-BERRETH, S. and JIANG, T. -X. (1996). Early events during avian skin appendage regeneration: Dependence on epithelial-mesenchymal interaction and order of molecular reappearance. $\mathrm{J}$. Invest. Dermatol. 107:639-646.

CHANG, C-H., JIANG, T-X., LIN, C-M., BURRUS, L. W., CHUONG, C-M. and WIDELITZ, R. (2004). Distinct Wnt members regulate the hierarchical morphogenesis of skin regions (spinal tract) and indivisual feathers. Mech. Dev. 121: 157-171.

CROWE, R., HENRIQUE, D., ISH-HOROWICZ, D. and NISWANDER, L. (1998). A new role for Notch and Delta in cell fate decisions: patterning the feather array. Development 125: 767-775.

DAI, X., SCHONBAUM, C., DEGENSTEIN, L., BAI, W., MAHOWALD, A. and FUCHS E. (1998). The ovo gene required for cuticle formation and oogenesis in flies is involved in hair formation and spermatogenesis in mice. Genes Dev. 12: 3452-3463.

DENSON, L. A., KARPEN, S. J., BOGUE, C. W. and JACOBS H. C. (2000). Divergent homeobox gene Hex regulates promoter of the $\mathrm{Na}+$-dependent bile acid cotransporter. Am. J. Physiol. Gastrointest. Liver Physiol. 279, G347G355.

GEHRING, W. J., AFFOLTER, M. and BURGLIN, T. (1994). Homeodomain proteins. Annu. Rev. Biochem. 63: 487-526.

GODWIN, A. R. and CAPECCHI, M. R. (1998). Hoxc13 mutant mice lack external hair. Genes Dev. 12: 11-20

HUELSKEN, J., VOGEL, R., ERDMANN B., COTSARELIS, G. and BIRCHMEIER, W. (2001). $\beta$-catenin controls hair follicle morphogenesis and stem cell differentiation in the skin. Cel/105: 533-545.

JAVE-SUAREZ, L. F., WINTER, H., LANGBEIN, L., ROGERS, M. A. and SCHWEIZER, J. (2002). HOXC13 is involved in the regulation of human hair keratin gene expression. J. Biol. Chem. 277: 3718-3726.

JIANG, T. X., LIU, Y. H., WIDELITZ, R. B. MAXON, R. E. and CHUONG, C. M. (1999). Epidermal dysplasia and abnormal hair follicles in transgenic mice overexpressing homeobox gene Msx-2. J. Invest. Dermatol. 113: 230-237.

KAWAKAMI, Y., WADA, N., NISHIMATSU, S. and NOHNO, T. (2000). Involvement of frizzled-10 in Wnt-7a signaling during chick limb development. Dev. Growth Differ. 42: 561-569.

KENG, V. W., YAGI, H., IKAWA, M., NAGANO, T., MYNTZ, Z., YAMADA, K., TANAKA, T., SATO, A., MURAMATSU, I., OKABE, M., SATO, M. and NOGUCHI, T. (2000). Homeobox gene Hex is essential for onset of mouse embryonic liver development and differentiation of the monocyte lineage. Biochem. Biophys. Res. Comm. 276: 1155-1161.

KISHIMOTO, J., BURGESON, R. E. and MORGAN, B. A. (2000). Wnt signaling maintains the hair-inducing activity of the dermal papilla. Genes Dev. 14:11811185.

KOSAKA, Y., AKIMOTO, Y., OMOTO, Y., OBINATA, A. and HIRANO, H. (2000a). Expression of the HB9 homeobox gene concomitant with proliferation accompanying epidermal stratification during development of chick embryonic tarsometatarsal skin. Histochem. J. 32: 275-280.

KOSAKA, Y., AKIMOTO, Y., OBINATA, A. and HIRANO, H. (2000b. ) Localization of HB9 homeobox gene mRNA and protein during the the early stages of chick feather development. Biochem. Biophys. Res. Commu. 276: 1112-1117.

LI, B., MACKAY, D. R., DAI, Q., LI, T. W. H., NAIR, M., FALLAHI, M., SCHONBAUM, C. P., FANTES, J., MAHOWALD, A. P., WATERMAN, M. L., FUCHS, E. and DAI, X. (2002). The LEF1/ק-catenin complex activates movo1, a mouse homolog of Drosophila ovo required for epidermal appendage differentiation. Proc. Natl. Acad. Sci. USA 99:6064-6069.

MARTINEZ-BARBERA, J. P. and BEDDINGTON, R. S. (2001). Getting your head around Hex and Hesx 1: forebrain formation in mouse. Int. J. Dev. Biol. 45: 327336.

MARTINEZ-BARBERA, J. P., CLEMENTS, M., THOMAS, P., RODRIGUEZ, T., MELOY, D., KIOUSSIS, D. and BEDDINGTON, R. S. (2000). The homeobox gene $\mathrm{Hex}$ is required in definitive endodermal tissues for normal forebrain, liver and thyroid formation. Development 127: 2433-2445.

MILLAR, S. E., WILLERT, K., SALINAS, P. C., ROELINK, H., NUSSE, R., SUSSMAN, D. J. and BARSH, G. S. (1999). Wnt signaling in the control of hair growth and 
structure. Dev. Biol. 207: 133-149.

NORAMLY, S., FREEMAN, A. and MORGAN, B.A. (1999). $\beta$-catenin signaling can initiate feather bud development. Development 126: 3509-3521.

NOVEEN, A., JIANG, T-X, TING-BERRETH, S. A. \& CHUONG, C-M. (1995). Homeobox genes Msx-1 and Msx-2 are associated with induction and growth of skin appendages. (1995). J. Invest. Dermatol. 104: 711-719.

OBINATA, A., AKIMOTO, Y., HIRANO, H. and ENDO, H. (1991). Stimulation by $\mathrm{Bt}_{2} \mathrm{CAMP}$ of epidermal mucous metaplasia in retinol-pretreated chick embryonic cultured skin and its inhibition by herbimycin A, an inhibitor for protein-tyrosine kinase. Exp. Cell Res. 193:36-44.

OBINATA, A., AKIMOTO, Y., OMOTO, Y. and HIRANO, H. (2001). Increase in expression of the homeobox gene, $G b \times 1$, in retinol-induced epidermal mucous metaplasia. Biochem. Biophys. Res. Commu. 280: 1055-1061.

OBINATA, A., AKIMOTO, Y., OMOTO, Y. and HIRANO, H. (2002). Expression of Hex homeobox gene during skin development: Increase in epidermal cell proliferation by transfecting the Hex to the dermis. Develop. Growth. Differ. 44: 281-292.

OBINATA, A. and AKIMOTO, Y. (2005). Expression of Hex during feather bud development. Int. J. Dev. Biol. 49: 885-890.

OLIVERA-MARTINEZ, I., THELU, J., TEILLET, M-A. and DHOUAILLY, D. (2001). Dorsal dermis development depends on a signal from the dorsal neural tube, which can be substituted by Wnt1. Mech. Dev. 100: 233-244.

OLIVERA-MARTINEZ, I., MISSIER, S., FRABOULET, S., THELU, J. and DHOUAILLY, D. (2002). Differential regulation of the chick dorsal thoracic dermal progenitors from the medial dermomyotome. Development 129: 47634772.

PATEL, K., MAKARENKOVA, H. and JUNG, H. S. (1999). The role of long range, local and direct signaling molecules during chick feather bud development involving the BMPs, follistatin and the Eph receptor tyrosine kinase Eph-A4. Mech. Dev. 86: 51-62.

PAYRE, F., VINCENT, A. and CARRENO, S. (1999). ovo/svbintegrates Wingless and DER pathways to control epidermis differentiation. Nature 400: 271-275.

REDDY, S. ANDL, T., BAGASRA, A., LU, M. M., EPSTEIN, D. J., MORRESEY, E. E. and MILLAR, S. E. (2001). Characterization of Wnt gene expression in developing and postnatal hair follicles and identification of Wnt5a as a target of Sonic hedgehog in hair follicle morphogenesis. Mech. Dev. 107: 69-82.

RODRIGUEZ-NIEDENFUHR, M., DATHE, V., JACOB, H. J., PROLS, F. and CHRIST, B. (2003). Spatial and temporal pattern of Wnt- 6 expression during chick development. Anat. Embryol. 206: 447-451.

SCAAL, M., PROLS, F., FUCHTBAUER, E-M., PATEL, K., HORNIK, C., KOHLER, T., CHRIST, B. and BRAND-SABERI, B. (2002). BMPs induce dermal markers and ectopic feather tracts. Mech. Dev. 110: 51-60.
SENGEL, P. (1976). Morphogenesis of Skin. Cambridge University Press, Cambridge.

SMOLA, H., THIEKOTTER, G. and FUSENIG, N. E. (1993). Mutual induction of growth factor gene expression by epidermal-dermal cell interaction. J. Cell Biol. 122: 417-429.

SONG, H., WANG, Y. and GOETINCK, P. F. (1996). Fibroblast growth factor 2 can replace ectodermal signaling for feather development. Proc. Natl. Acad. Sci. USA 93: 10246-10249.

TING-BERRETH, S.A. and CHUONG, C-M. (1996). Sonic hedgehog in feather morphogenesis: Induction of mesenchymal condensation and association with cell death. Dev. Dynamics 207: 157-170.

VIALLET, J. P., PRIN, F., OLIVERA-MARTINEZ, I., HIRSINGER, E., POURQUIE, O. and DHOUAILLY, D. (1998). Chick Delta-1 gene expression and the formation of the feather primordia. Mech. Dev. 72: 159-168.

WAKAMATSU, Y., MAYNARD, T. M. and WESTON J. A. (2000). Fate determination of neural crest cells by NOTCH-mediated lateral inhibition and asymmetrical cell division during gangliogenesis. Development 127: 2811-2821

WIDELITZ, R. B., JIANG, T. X., NOVEEN, A., CHEN, C. W. and CHUONG, C. M. (1996). FGF induces new feather buds from developing avian skin. J. Invest. Dermatol. 107: 797-803.

WIDELITZ, R. B., JIANG, T-X., CHEN, C-W, J., STOTT, N. S. and CHUONG, C-M. (1999). Wnt7a in feather morphogenesis:Involvement of anterior-posterior asymmetry and proximal-distal elongation demonstrated with an in vitro reconstituted model. Development 126: 2577-2587.

WIDELITZ R. B., JIANG T. X., LU J. and CHUONG C. M. (2000). Beta-catenin in epithelial morphogenesis: conversion of part of avian foot scales into feather buds with a mutated beta-catenin. Dev. Biol. 219: 98-114.

WODARZ, A. and NUSSE, R. (1998). Mechanism of Wnt signaling in development. Annu. Rev. Cell Dev. Biol. 14: 59-88.

YATSKIEVYCH, T. A., PASCOE, S. and ANTIN, P. K. (1999). Expression of the homeobox gene Hex during early stages of chick embryo development. Mech. Dev. 80: 107-109.

ZHANG, W., YATSKIEVYCH, T. A., CAO, X. and ANTIN, P. B. (2002). Regulation of Hex gene expression by a Smads-dependent signaling pathway. J. Biol. Chem. 277: 45435-45441.

Received: May 2005

Reviewed by Referees: July 2005

Modified by Authors and Accepted for Publication: August 2005

Edited by: Makoto Asashima 